\title{
Measuring School-Family Conflict and Enrichment in University Student Parents: A Measurement Validation Study
}

Tricia van Rhijn

University of Guelph

Anita Acai

McMaster University

Donna S. Lero

University of Guelph

\begin{abstract}
The purpose of this study was to extend work-family research to the schoolfamily context by adapting Carlson and colleagues' Work-Family Conflict and Enrichment scales. Using two samples of student parents primarily from Canadian universities, the adapted scales were assessed for reliability, construct validity, and factor structure. The measures had three factors for school-family conflict (school-to-family conflict, behaviour-based conflict, and family-to-school conflict) and five for school-family enrichment (schoolto-family growth and affect; and family-to-school development, affect, and efficiency). The two adapted scales were confirmed to be reliable and valid for use with university student parents. Data from the confirmatory factor analysis provided strong support for the factor structure of the School-Family Enrichment Scale, but suggested that additional testing and development of the School-Family Conflict Scale may be required.
\end{abstract}

\section{Résumé}

Le but de cette étude est d'étendre la recherche de conciliation travailfamille au contexte école-famille en adaptant une échelle crée par Carlson et ses collègues. À l'aide de deux échantillons de parents-étudiants provenant 
surtout d'universités canadiennes, nous avons évalué la fiabilité, la validité et la structure factorielle des échelles adaptées. Les mesures sont compromises de trois facteur relié au conflit école-famille (conflit entre l'école et la famille, conflits de comportement et conflits entre les familles) et cinq factor reliées à l'enrichissement école-famille (l'effet de croissance entre l'école et la famille, et le développement, l'effet et l'efficacité entre la famille et l'école). Les deux échelles ont été confirmées en étant fiables et valides pour les parents étudiants universitaires. Les données d'analyse ont appuyé la structure factorielle de l>échelle d enrichissement école-famille, mais suggère que des développements et des tests supplémentaires pourraient être requis pour l'échelle de conflit école-famille.

\section{Introduction}

Adult learners are increasingly enrolling in post-secondary programs to improve their earnings potential, gain credentials for career advancement, or to qualify to work in a new field (Kerr, 2011; Kuh, Kinzie, Buckley, Bridges, \& Hayek, 2006). Post-secondary study can also be considered an important tool for becoming self-sufficient as mandated in welfare-to-work reforms, in which qualification for welfare benefits is contingent upon mandatory work measures (Theodore \& Peck, 1999). Accordingly, policies that support adult education and lifelong learning are of increasing interest. One group of mature students, largely overlooked, consists of parents pursuing post-secondary study (for the purposes of this paper, "school" is used to refer to post-secondary studies). It is generally understood that these students face additional challenges persisting with and completing their studies, such as integrating the reciprocal and multifaceted relationships between their school and family lives (van Rhijn, Lero, Bridge, \& Fritz, 2016); however, published literature on the unique challenges student parents face or their support needs remains sparse.

Prior research indicates that being a parent, in itself, reduces the likelihood of postsecondary attendance (Butlin, 1999; Looker, 1997). Nevertheless, student parents are a significant minority population on university and college campuses in Canada. Data from the Canadian Survey of Labour and Income Dynamics indicated that approximately $11 \%$ of university students and 17\% of college students were student parents in 2004 (van Rhijn, Smit Quosai, \& Lero, 2011); follow-up analysis of the Canadian Labour Force Survey data indicate that student parent enrolment remains at 11\% in October 2017 (Statistics Canada, 2017). An understanding of how student parents manage their multiple role demands is required to develop evidence-based policies, programs, and resources that can reduce the challenges and barriers faced by this frequently overlooked population. These programs and resources could also address access issues and support program completion, benefiting both student parents and their children. Therefore, the purpose of this study was to adapt and validate work-family conflict and work-family enrichment measures for use with student parents to begin to explore the relationships between their multiple roles.

\section{What Do We Know About Student Parents?}

Student parents are found to differ in several significant ways from their more traditionally aged and circumstanced student counterparts (childless students aged 18 to 22). 
Student parents are older (averaging 37.6 years) and more likely to be employed (50\% compared to $42 \%$ ) than typical undergraduate students (Holmes, 2005). Considering higher education as a whole (i.e., averaged across all fields of study), student parents are also more likely to be female; in $2005,70 \%$ were female, compared to $51 \%$ of non-parent students (van Rhijn et al., 2011). Moreover, student parents are more likely to study parttime than non-parents: 51\% studied part-time, compared to only $19 \%$ of non-parents (van Rhijn et al., 2011). Reasons for part-time study are indicative of gender differences within the student parent population, with men more likely to report employment-related reasons and women more likely to report childcare responsibilities as their primary reason for pursuing part-time studies (van Rhijn et al., 2011). Finally, students with dependent children face an increased likelihood of interrupting their studies (Holmes, 2005; van Rhijn et al., 2011), increased role strain (Home, 1997), and more stress than traditional students when entering the post-secondary environment (Padula, 1994). Student parents often return to school after an extended absence from the educational environment. They are also challenged by interacting with younger peers with different values, interests, and priorities (Padula, 1994; Wyatt, 2011).

Aside from broader social and economic factors such as social exclusion and poverty, research investigating the unique circumstances of student parents has demonstrated that both personal and institutional factors influence the academic success of this population. Female student parents' success has been related to the following personal factors: personal ambition, social maturity, personal experience, effort and discipline in balancing studying time and parenting, and self-confidence (Van Stone, Nelson, \& Niemann, 1994). Student parents with high student and parental self-efficacy have been found to experience less psychological distress and have higher self-esteem and life satisfaction (Quimby \& O'Brien, 2006). Yet, there is some evidence to suggest that student parents may have lower overall scores on measures of student psychosocial development than traditional students (MacAri, Maples, \& D’Andrea, 2005). Institutional factors such as peer support, access to university services, and positive interactions with faculty have also been found to influence academic success, intent to remain in school, and overall school satisfaction (Kuh et al., 2006; Van Stone et al., 1994; Wyatt, 2011).

\section{From Work-Family to School-Family}

Work-family conflict theories propose that characteristic work stressors such as high demands, low levels of control, a fast pace, and frequent deadlines impact both quality of parenting and quality of life (Crouter \& McHale, 2005; Mullen, Kelley, \& Kelloway, 2008). All of these stressors exist for student parents as well. Work-family conflict is a form of conflict between work and family roles resulting from incompatible demands (Greenhaus \& Beutell, 1985), and is considered to be a bidirectional process (i.e., two domains, work-to-family and family-to-work). Three forms of conflict have been identified: time-based, strain-based, and behaviour-based conflict (Carlson, Kacmar, \& Williams, 2000). Time-based conflict occurs when time devoted to one role takes away from or competes with time in another role, with time viewed as a fixed resource. Strain-based conflict occurs when strain experienced in one role intrudes into another role (Carlson et al., 2000; Voydanoff, 2005). Behaviour-based conflict occurs when specific behaviours required for one role are incompatible with another role. 
An extensive body of research has explored the impact of multiple roles for employed parents and the relationships between work and family roles (e.g., Byron, 2005; Carlson et al., 2000; Frone, Yardley, \& Markel, 1997; Greenhaus \& Beutell, 1985; Greenhaus \& Powell, 2003; Hammer, Cullen, Neal, Sinclair, \& Shafiro, 2005; Kinnunen, Feldt, Geurts, \& Pulkkinen, 2006; Voydanoff, 2005). Work-family conflict has been demonstrated to result in negative behavioural and emotional outcomes for employed parents and predict outcomes in the family domain including reduced satisfaction with family life and psychological strain (Carlson et al., 2000). Family-to-work conflict affects the work domain and predicts dissatisfaction with work and reduced work performance (Carlson et al., 2000; Frone et al., 1997). Well-validated measures have been developed to measure the bidirectional components of work-family conflict, including one by Carlson et al. (2000) that measures the three types of conflict (time-based, strain-based, and behaviour-based) in each of the two domains, family-to-work and work-to-family.

Correspondingly, school-family conflict is defined as conflict between student and family roles resulting from incompatible demands. The three types of conflict conceptualized for work-family conflict are applicable to the school-family context. Hammer, Grigsby, and Woods (1998) measured school-family conflict in student parents by adapting an eight-item measure of work-family spillover and found that student parents experienced high levels of family-to-school conflict. They suggested that school-family conflict may impact academic success in much the same way that work-family conflict can impact parenting; yet, to the best of the authors' (of the current paper) knowledge, no school-family conflict measures have been created or validated for this population.

Work-family enrichment is defined as the "extent to which experiences in one role improve the quality of life in the other role" (Greenhaus \& Powell, 2003, p. 73). Work-family enrichment is also conceptualized as a bidirectional process and considers resources/ assets that can be drawn on to cope with a challenge or problem. Quality of life improvements relate to performance and affect; work-family enrichment occurs when resources or assets in one role improve role performance or affect in the other role. Demonstrated work-family enrichment outcomes include improved mental health and well-being (Hanson, Hammer, \& Colton, 2006).

In developing a measure of work-family enrichment, Carlson, Kacmar, Wayne, and Grzywacz (2006) identified six distinct dimensions of work-family enrichment, three for work-to-family and three for family-to-work enrichment. The three dimensions of workto-family enrichment included development, affect, and capital. The three dimensions of family-to-work enrichment included development, affect, and efficiency, with definitions presented in Table 1.

School-family enrichment is similarly defined as the extent to which experiences in the school or family role improve the quality of life in the other role. The three types of enrichment conceptualized for each of the work-family domains appear applicable to the school-family context. Thus, the three dimensions of school-to-family enrichment are development, affect, and capital. The three dimensions of family-to-school enrichment are development, affect, and efficiency. No previous research has been located that directly measures school-family enrichment. It is possible that school-family enrichment may act as a moderator of school-family conflict, lessening the impact of conflict on outcomes such as psychological well-being (e.g., role strain and stress) and performance (e.g., academic success). 
Table 1. Dimensions and definitions of work-to-family enrichment and family-to-work enrichment

\begin{tabular}{ll}
\hline Dimensions of work-to-family enrichment & Definition \\
\hline Work-family development & $\begin{array}{l}\text { The acquisition or improvement of skills, knowl- } \\
\text { edge, or behaviours resulting from involvement in } \\
\text { one's work role that assist one to become a better } \\
\text { family member. }\end{array}$ \\
A positive emotional state or attitude from in- \\
volvement in one role that assists one to be a bet- \\
ter family member. \\
The development of psychosocial resources (e.g., \\
Sense of security, accomplishment, or fulfilment) \\
at work that assists one to become a better family \\
member.
\end{tabular}

\section{Purpose of This Study}

There are notable similarities between work-family conflict/enrichment and schoolfamily conflict/enrichment. From a broad perspective, both work and school represent outside commitments that can either conflict with or enrich an individual's family life (or vice versa). As a result, Carlson et al.'s (2000) Work-Family Conflict Scale and Carlson et al.'s (2006) Work-Family Enrichment Scale were adapted, with permission, for use in measuring school-family conflict and school-family enrichment, respectively. Adaptation involved simple wording changes/substitutions to reflect the school-family context (e.g., changing "work" or "job" to "school" or "schoolwork" and "career" to "education") for use as a comprehensive measure of both the conflict and enrichment occurring between the school and family contexts. They differ from other adapted scales such as Xu and Song's (2013) Work-Family-School Role Conflicts Scale, which includes items from other workfamily conflict scales and has only been validated for use among registered nurses, and Haslam, Filus, Morawska, and Fletcher's (2015) Work-Family Conflict Scale, which is designed to measure work-family (as opposed to school-family) conflict among parents of young children in clinical settings. The purpose of the present study was to examine the utility of the two adapted measures for investigating school-family conflict and enrichment among undergraduate students who are parents (undergraduate student parents). 


\section{Methods}

In order to examine the utility of the new measures, three steps were identified to meet the study's purpose, including exploratory factor analysis (EFA), assessment of the scales' reliability and construct validity, and confirmatory factor analysis (CFA).

\section{Step 1: Exploratory Factor Analysis}

To determine if the factor structure of each adapted scale was the same as that of the original, EFA was conducted on the school-family conflict and enrichment data. Individual items were also examined to determine how well they functioned in the adapted scales.

Sample and procedure. A 129-item online survey was completed by 339 undergraduate student parents with one or more dependent child less than 18 years of age in the fall of 2008. Participants used a direct link to access the anonymous online survey and were required to read and agree to the informed consent information prior to beginning the survey.

The sample consisted of 295 women and 44 men enrolled as full-time or part-time students at 34 colleges and universities across Canada (Table 2). A majority (73\%) of the sample was obtained from four post-secondary institutions located in urban centres: a small liberal arts university in Nova Scotia; two mid-sized comprehensive universities in Ontario; and one mid-sized college in Ontario. A majority of participants were in university (84\%) and partnered (married or common-law) (66\%). Participants averaged 34.56 years of age with a mean of 1.75 children (range: 1 to 6). Just over half (52\%) had at least one child under 6 years of age.

Table 2. Sample characteristics

\begin{tabular}{lccrc}
\hline & \multicolumn{2}{c}{$\begin{array}{c}\text { Sample 1 (Steps 1 \& 2) } \\
\text { Total }(N=339)\end{array}$} & $\begin{array}{c}\text { Sample 2 (Step 3) } \\
\text { Total }(N=317)\end{array}$ \\
\cline { 2 - 5 } & Frequency & Percent & Frequency & Percent \\
\hline Gender & & & & \\
Female & 295 & 87 & 241 & 76 \\
Male & 44 & 13 & 76 & 24 \\
Age of Youngest Child & & & & \\
Preschool/Kindergarten (0-6) & 177 & 52 & 174 & 55 \\
School Age (6-17) & 162 & 48 & 137 & 43 \\
Adult (18+) & -- & -- & 6 & 2 \\
Institution type & & & & \\
University & 283 & 84 & 309 & 97 \\
College & 56 & 17 & -- & -- \\
Study status & & & & \\
Full-time & 189 & 56 & 163 & 51 \\
Part-time & 150 & 44 & 152 & 48 \\
Work status while attending school & & & & \\
Working & 231 & 68 & 186 & 59 \\
Not working & 108 & 32 & 121 & 38 \\
\hline
\end{tabular}

Note: Percentages may not total $100 \%$ as some participants indicated that they preferred not to answer certain questions or left their response blank. 
Measures. Adapted from Carlson et al.'s (2000) Work-Family Conflict Scale, schoolfamily conflict was measured using an 18-item self-report questionnaire (see Table 3 for items) scored on a 5 -point Likert scale $(1=$ strongly disagree to $5=$ strongly agree). Following the structure of the original instrument, the scale consisted of the six subscales previously described.

Table 3. Adaptation of the Work-Family Conflict Scale

\begin{tabular}{|c|c|c|}
\hline Sub-scale & Item \# & Item \\
\hline \multicolumn{3}{|l|}{ School-to-family conflict } \\
\hline \multirow{3}{*}{$\begin{array}{l}\text { Time-based school } \\
\text { interference with } \\
\text { family }\end{array}$} & 1.1 & $\begin{array}{l}\text { My school keeps me from my family activities more than I } \\
\text { would like. }\end{array}$ \\
\hline & 1.2 & $\begin{array}{l}\text { The time I must devote to my schoolwork keeps me from } \\
\text { participating equally in household responsibilities and } \\
\text { activities. }\end{array}$ \\
\hline & 1.3 & $\begin{array}{l}\text { I have to miss my family activities due to the amount of } \\
\text { time I must spend on school responsibilities. }\end{array}$ \\
\hline \multirow{3}{*}{$\begin{array}{l}\text { Strain-based school } \\
\text { interference with } \\
\text { family }\end{array}$} & 1.4 & $\begin{array}{l}\text { When I get home from school I am often too frazzled to } \\
\text { participate in family activities/responsibilities. }\end{array}$ \\
\hline & 1.5 & $\begin{array}{l}\text { I am often so emotionally drained when I get home from } \\
\text { school that it prevents me from contributing to my family. }\end{array}$ \\
\hline & 1.6 & $\begin{array}{l}\text { Due to all the school pressures, sometimes I am too } \\
\text { stressed to do the things I enjoy at home. }\end{array}$ \\
\hline \multirow{3}{*}{$\begin{array}{l}\text { Behaviour-based } \\
\text { school interference } \\
\text { with family }\end{array}$} & 1.7 & $\begin{array}{l}\text { The problem-solving behaviours I use for school are not } \\
\text { effective in resolving problems at home. }\end{array}$ \\
\hline & 1.8 & $\begin{array}{l}\text { Behaviour that is effective and necessary for me at school } \\
\text { would be counterproductive at home. }\end{array}$ \\
\hline & 1.9 & $\begin{array}{l}\text { The behaviours I perform that make me effective at school } \\
\text { do not help me to be a better parent and/or spouse/part- } \\
\text { ner. }\end{array}$ \\
\hline \multicolumn{3}{|l|}{ Family-to-school conflict } \\
\hline \multirow{3}{*}{$\begin{array}{l}\text { Time-based family } \\
\text { interference with } \\
\text { school }\end{array}$} & 1.10 & $\begin{array}{l}\text { The time I spend on family responsibilities often inter- } \\
\text { feres with my school responsibilities. }\end{array}$ \\
\hline & 1.11 & $\begin{array}{l}\text { The time I spend with my family often causes me not to } \\
\text { spend time in activities at school that would be helpful to } \\
\text { my education. }\end{array}$ \\
\hline & 1.12 & $\begin{array}{l}\text { I have to miss school activities due to the amount of time I } \\
\text { must spend on family responsibilities. }\end{array}$ \\
\hline
\end{tabular}




\begin{tabular}{ccl}
\hline Sub-scale & Item \# & Item \\
\hline $\begin{array}{l}\text { Strain-based family in- } \\
\text { terference with school }\end{array}$ & 1.13 & $\begin{array}{l}\text { Due to stress at home, I am often preoccupied with family } \\
\text { matters at school. }\end{array}$ \\
& 1.14 & $\begin{array}{l}\text { Because I am often stressed from family responsibilities, I have } \\
\text { a hard time concentrating on my schoolwork. } \\
\text { Tension and anxiety from my family life often weakens my } \\
\text { ability to do well in school. }\end{array}$ \\
\hline $\begin{array}{l}\text { Family-to-school conflict } \\
\text { Behaviour-based fam- } \\
\text { ily interference with }\end{array}$ & 1.16 & $\begin{array}{l}\text { The behaviours that work for me at home do not seem to } \\
\text { be effective at school. } \\
\text { Behaviour that is effective and necessary for me at home } \\
\text { would be counterproductive at school. } \\
\text { The problem-solving behaviour that works for me at home does } \\
\text { not seem to be useful at school. }\end{array}$ \\
\hline
\end{tabular}

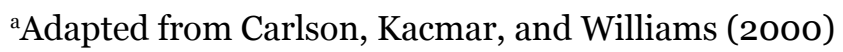

Adapted from Carlson et al.'s (2006) Work-Family Enrichment Scale, school-family enrichment was measured using an 18-item self-report questionnaire (see Table 4 for items) scored on a 5 -point Likert scale $(1=$ strongly disagree to $5=$ strongly agree). Following the structure of the original instrument, the scale consisted of the six subscales previously described.

Table 4. Adaptation of the Work-Family Enrichment Scale

\begin{tabular}{|c|c|c|}
\hline Sub-scale & Item \# & Item: "My involvement in my schooling..." \\
\hline \multicolumn{3}{|l|}{ School-to-family enrichment } \\
\hline \multirow[t]{3}{*}{ School-to-family development } & 2.1 & $\begin{array}{l}\text { Helps me to understand different viewpoints and } \\
\text { this helps me be a better family member. }\end{array}$ \\
\hline & 2.2 & $\begin{array}{l}\text { Helps me to gain knowledge and this helps me be } \\
\text { a better family member. }\end{array}$ \\
\hline & 2.3 & $\begin{array}{l}\text { Helps me acquire skills and this helps me be a bet- } \\
\text { ter family member. }\end{array}$ \\
\hline \multirow[t]{3}{*}{ School-to-family affect } & 2.4 & $\begin{array}{l}\text { Puts me in a good mood and this helps me be a } \\
\text { better family member. }\end{array}$ \\
\hline & 2.5 & $\begin{array}{l}\text { Makes me feel happy and this helps me be a better } \\
\text { family member. }\end{array}$ \\
\hline & 2.6 & $\begin{array}{l}\text { Makes me cheerful and this makes me be a better } \\
\text { family member. }\end{array}$ \\
\hline
\end{tabular}




\begin{tabular}{|c|c|c|}
\hline Sub-scale & Item \# & Item: "My involvement in my schooling..." \\
\hline \multirow[t]{3}{*}{ School-to-family capital } & 2.7 & $\begin{array}{l}\text { Helps me feel personally fulfilled and this helps } \\
\text { me be a better family member. }\end{array}$ \\
\hline & 2.8 & $\begin{array}{l}\text { Provides me with a sense of accomplishment and } \\
\text { this helps me be a better family member. }\end{array}$ \\
\hline & 2.9 & $\begin{array}{l}\text { Provides me with a sense of success and this helps } \\
\text { me be a better family member. }\end{array}$ \\
\hline \multicolumn{3}{|l|}{ Family-to-school enrichment } \\
\hline \multirow[t]{3}{*}{ Family-to-school development } & 2.10 & $\begin{array}{l}\text { Helps me to gain knowledge and this helps me be } \\
\text { a better student. }\end{array}$ \\
\hline & 2.11 & $\begin{array}{l}\text { Helps me acquire skills and this helps me be a bet- } \\
\text { ter student. }\end{array}$ \\
\hline & 2.12 & $\begin{array}{l}\text { Helps me expand my knowledge of new things and } \\
\text { this helps me be a better student. }\end{array}$ \\
\hline \multirow[t]{3}{*}{ Family-to-school affect } & 2.13 & $\begin{array}{l}\text { Puts me in a good mood and this helps me be a } \\
\text { better student. }\end{array}$ \\
\hline & 2.14 & $\begin{array}{l}\text { Makes me feel happy and this helps me be a better } \\
\text { student. }\end{array}$ \\
\hline & 2.15 & $\begin{array}{l}\text { Makes me cheerful and this helps me be a better } \\
\text { student. }\end{array}$ \\
\hline \multirow[t]{3}{*}{ Family-to-school efficiency } & 2.16 & $\begin{array}{l}\text { Requires me to avoid wasting time at school or on } \\
\text { schoolwork and this helps me be a better student. }\end{array}$ \\
\hline & 2.17 & $\begin{array}{l}\text { Encourages me to use my school time in a focused } \\
\text { manner and this helps me be a better student. }\end{array}$ \\
\hline & 2.18 & $\begin{array}{l}\text { Causes me to be more focused at school or on } \\
\text { schoolwork and this helps me be a better student. }\end{array}$ \\
\hline
\end{tabular}

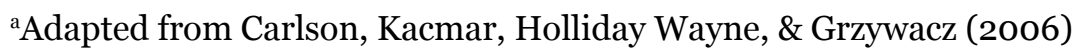

Analyses. IBM's Statistical Package for the Social Sciences (SPSS) version 24 was used to extract maximum likelihood estimation and rotated using an oblique rotation procedure (promax). Maximum likelihood estimation is a widely used factor-extraction procedure with desirable statistical properties (Fabrigar, Wegener, MacCallum, \& Strahan, 1999) and was selected for use despite being limited by its assumption of multivariate normality. An oblique rotation procedure was selected, as the factors have been determined to be related in previous work-family conflict research and were expected to also be related for school-family research. Four, five, and six-factor solutions were extracted. As per Tabachnick and Fidell (2013), the following analyses were used to select the best fitting model: eigenvalues greater than 1, goodness-of-fit test, size of communalities, size of residuals from reproduced correlations, strength and pattern of factor loadings/rotated factor loadings and number of split loadings, and total variance explained by the model. 


\section{Step 2: Assessment of the Scales' Reliability and Construct Validity}

Assessment of the adapted scales' reliability and construct validity was conducted using the same sample as described in Step 1. Internal reliability was assessed using Cronbach's alpha reliability estimates, with Spearman-Brown statistics also provided for the two-item scales as they are demonstrated to provide a more appropriate estimate of reliability for two-item scales (Eisinga, Grotenhuis, \& Pelzer, 2013). Construct validity was assessed using a correlational analysis of a nomological network of relationships based on previous work-family research. Means, standard deviations, and reliability estimates for the study variables are presented in Table 5. Measures were selected based on their theoretical applicability to the school-family context and the work-family conflict and enrichment literature review.

Salience of family role. Defined as the meaning, importance, or centrality of a specific role to an individual, salience of the family role was measured using two items adapted from Lodahl and Kejner (1965) used in previous work-family research (Carlson et al., 2006; Greenhaus \& Powell, 2003). Salience of the family role was measured on a 5 -point Likert scale ( $1=$ strongly disagree to $5=$ strongly agree). The two items are as follows: "The major satisfaction in my life comes from my family," and "The most important things that happen to me involve my family."

Salience of student role. To measure salience of the student role, two items analogous to the family salience items were written for the purposes of this study, utilizing the same 5 -point Likert scale ( $1=$ strongly disagree to $5=$ strongly agree). The two items are as follows: "Going to school gives me a strong feeling of satisfaction" and "School is a very important part of my life."

Academic self-efficacy. Defined as a self-evaluation of competence to complete academic tasks (e.g., studying, writing papers), this construct was measured using the Academic Self-efficacy Scale developed by Zajacova, Lynch, and Espenshade (2005). This scale was selected due to its construction for use with non-traditional undergraduate students and consists of 25 tasks rated on an 11-point scale $(1=$ not at all confident to $11=\mathrm{ex}-$ tremely confident) for level of confidence in one's ability to successfully complete the task. The scale consists of four subscales: Interaction at School; Performance Out of Class; Performance in Class; and Managing Work, Family, and School. The Managing Work, Family, and School subscale was not used due to redundancy when compared to the more comprehensive school-family conflict/enrichment measures. Several redundant items from the other subscales were also removed, resulting in a final 12-item scale, consisting of three subscales: Interaction at School (e.g., "Talking to my professors/instructors"), Performance Out of Class (e.g., "Keeping up with the required readings"), and Performance in Class (e.g., "Doing well on exams"), each with four items.

Parental self-efficacy. Defined as a self-evaluation of competence to complete parenting tasks, this construct was measured using the Parenting Self-Efficacy subscale from the Parenting Sense of Competence Scale (as cited in Johnston \& Mash, 1989). This scale was selected as a global measure of parenting self-efficacy and is a seven-item measure rated on a 6 -point Likert scale ( $1=$ strongly agree to $6=$ strongly disagree). A sample item from this scale is "If anyone can find the answer to what is troubling my child, I am the one." 
Table 5. Means, standard deviations and Cronbach's alpha reliability estimates for study variables

\begin{tabular}{|c|c|c|c|c|c|c|}
\hline Variable & $n$ & $\begin{array}{c}\text { Number of } \\
\text { items }\end{array}$ & Range & $M$ & $S D$ & $\begin{array}{c}\alpha(\text { Spearman- } \\
\text { Brown } \rho)\end{array}$ \\
\hline \multicolumn{7}{|l|}{ School-to-Family Conflict ${ }^{a}$} \\
\hline Time-based & 337 & 3 & $3-15$ & 10.47 & 3.00 & .78 \\
\hline Strain-based & 333 & 3 & $3-15$ & 9.95 & 2.96 & .84 \\
\hline Behaviour-based & 332 & 3 & $3-15$ & 8.39 & 2.55 & .71 \\
\hline \multicolumn{7}{|l|}{ Family-to-School Conflict ${ }^{\mathrm{a}}$} \\
\hline Time-based & 332 & 3 & $3-15$ & 9.65 & 2.69 & .75 \\
\hline Strain-based & 337 & 3 & $3-15$ & 9.21 & 3.03 & .86 \\
\hline Behaviour-based & 336 & 3 & $3-15$ & 8.28 & 2.46 & .84 \\
\hline \multicolumn{7}{|c|}{ School-to-Family Enrichment ${ }^{\mathrm{a}}$} \\
\hline Development & 338 & 3 & $3-15$ & 12.04 & 2.28 & .85 \\
\hline Affect & 338 & 3 & $3-15$ & 10.42 & 2.85 & .92 \\
\hline Capital & 336 & 3 & $3-15$ & 12.21 & 2.38 & .91 \\
\hline \multicolumn{7}{|c|}{ Family-to-School Enrichment ${ }^{\mathrm{a}}$} \\
\hline Development & 336 & 3 & $6-15$ & 11.51 & 2.39 & .87 \\
\hline Affect & 337 & 3 & $5-15$ & 11.29 & 2.40 & .90 \\
\hline Efficiency & 337 & 3 & $6-15$ & 10.89 & 2.71 & .81 \\
\hline Salience of Family Role ${ }^{a}$ & 336 & 2 & $2-10$ & 9.10 & 1.54 & $.87(.87)$ \\
\hline Salience of Student Role ${ }^{a}$ & 337 & 2 & $2-10$ & 8.50 & 1.66 & $.84(.84)$ \\
\hline \multicolumn{7}{|l|}{ Academic Self-Efficacy ${ }^{\mathrm{b}}$} \\
\hline Interaction at School & 299 & 4 & $8-44$ & 33.01 & 8.17 & .85 \\
\hline Performance out of Class & 331 & 4 & $6-44$ & 30.37 & 7.76 & .85 \\
\hline Performance in Class & 312 & 4 & $4-44$ & 30.82 & 7.74 & .87 \\
\hline Parental Self-Efficacy ${ }^{\mathrm{c}}$ & 328 & 7 & $7-42$ & 17.27 & 6.15 & .87 \\
\hline \multicolumn{7}{|l|}{ Perceived Social Support ${ }^{\mathrm{d}}$} \\
\hline Significant Other & 339 & 4 & $4-28$ & 19.88 & 5.88 & .95 \\
\hline Family & 339 & 4 & $4-28$ & 19.90 & 4.98 & .91 \\
\hline Friends & 339 & 4 & $4-28$ & 15.00 & $5 \cdot 43$ & .94 \\
\hline Positive Affect & 325 & 10 & $12-50$ & 35.89 & 7.56 & .90 \\
\hline Negative Affect ${ }^{\mathrm{e}}$ & 330 & 10 & $10-50$ & 25.88 & 9.41 & .90 \\
\hline Family Satisfaction ${ }^{\mathrm{f}}$ & 339 & 5 & $5-35$ & 25.27 & 7.10 & .95 \\
\hline School Satisfaction ${ }^{\mathrm{f}}$ & 339 & 5 & $11-35$ & 25.94 & 4.91 & .83 \\
\hline Life Satisfaction ${ }^{\mathrm{f}}$ & 339 & 5 & $5-35$ & 24.41 & 6.66 & .92 \\
\hline
\end{tabular}

${ }^{\text {a }}$ Measured on a scale from $1=$ strongly disagree to $5=$ strongly agree.

${ }^{\mathrm{b}}$ Measured on a scale from $1=$ not at all confident to $11=$ extremely confident.

${ }^{\mathrm{c}}$ Measured on a scale from $1=$ strongly disagree to $6=$ strongly agree.

${ }^{\mathrm{d}}$ Measured on a scale from $1=$ very strongly disagree to $7=$ very strongly agree.

${ }^{\mathrm{e}}$ Measured on a scale from $1=$ very slightly or not at all to $5=$ extremely.

${ }^{\mathrm{f}}$ Measured on a scale from $1=$ strongly disagree to $7=$ strongly agree. 
Perceived social support. Social support, although often operationalized as objective or quantitative measures of instrumental support (e.g., assistance with household tasks), can also be viewed as coping assistance offered by significant others during times of stress (Zimet, Dahlem, Zimet, \& Farley, 1988). The Multidimensional Scale of Perceived Social Support was designed to assess perceptions of the adequacy of social support from friends, family, and significant others (Zimet et al., 1988). Each of the subscales consists of four items measured on a 7-point Likert scale $(1=$ very strongly disagree to 7 = very strongly agree). Participants were requested to answer the items on the Friends subscale by referring to friends/peers available at school. Sample items from this scale are as follows: "I can count on my friends at school when things go wrong" (Friends), "My family is willing to help me make decisions" (Family), and "There is a special person in my life who is around when I am in need" (Significant Others).

Positive and negative affect. The Positive and Negative Affect Schedule (PANAS; Watson, Clark, \& Tellegen, 1988) is a 20-item self-report scale consisting of two subscales (positive affect and negative affect). The PANAS consists of 20 feelings, which participants rate to indicate the extent to which they have felt that way over a specific time period, defined for this study as the past semester. Items are rated on a 5-point Likert-type scale $(1=$ very slightly or not at all to $5=$ extremely). Two sample items for this measure are "Inspired" and "Nervous."

Family, school, and life satisfaction. Defined as the self-perception of one's own global quality of life, a widely utilized measure of this construct is Diener, Emmons, Larsen, and Griffin's (1985) Satisfaction with Life Scale (SWLS), as used in previous work-family research (e.g., Carlson et al., 2000). Created as an extension of Diener et al.'s SWLS, Alfonso, Allison, Rader, and Gorman's (1996) Extended Satisfaction with Life Scale (ESWLS) measures other domains of life, including family and school satisfaction in addition to general life satisfaction. Three subscales of the ESWLS were selected for use in this study: Family Satisfaction, School Satisfaction, and Life Satisfaction. Each of the subscales consists of five items measured on a 7-point Likert scale $(1=$ strongly disagree to $7=$ strongly agree). Sample items from each of the three subscales are as follows: "The conditions of my family life are excellent" (Family), "The education I get at school is great" (School), and "I am satisfied with my life" (Life).

\section{Step 3: Confirmatory Factor Analysis}

In this step, the fit of the three-factor school-family conflict and five-factor schoolfamily enrichment models, selected as best fitting from the EFA, were evaluated using CFA.

Sample and procedure. Data used in the CFA were obtained from the Mature Student Experience Survey, a longitudinal study of mature students examining well-being, motivations for attending university, and student experiences (van Rhijn \& Poser, 2013). The three-year study (2010-2013) collected data at six time points using an online survey with open- and closed-ended questions; data for this CFA were from the fifth time point, in the fall of 2012. Participants were students aged 25 or older enrolled in undergraduate study and recruited from four post-secondary institutions in southern Ontario that agreed to support recruitment efforts. Registrars' offices assisted with email recruitment over the three-year period. The survey was completed by 1,537 mature students; of these, 317 were student parents. Thus, the final sample consisted of 241 women and 76 men 
enrolled at one of four institutions across Ontario (Table 2). Nearly all of the students in the sample were enrolled in a university program (98\%) and most were partnered (married or common-law) (70\%). Participants had a mean age of 39.18 years with an average of 1.85 children (range: 1 to 6). Slightly more than half (55\%) had at least one child under 6 years of age. Independent $t$-tests and chi-square analyses completed to compare this sample to the first sample indicated some significant differences, including being older $(t$ $=-7.55, p<.001)$, having an older youngest child $(t=-3.60, p<.001)$, and having more female participants $\left(\chi^{2}=13.25, p<.001\right)$. The samples were not significantly different based on participants' average number of children $(t=1.07, p=.29)$, their enrolment status in full- or part-time study $\left(\chi^{2}=3.20, p=.20\right)$, or whether they were partnered or single $\left(\mathrm{X}^{2}=1.50, p=.22\right)$.

Measures. School-family conflict and school-family enrichment were measured using the scales previously described in Step 1.

Analyses. The fit of the three-factor school-family conflict model and the five-factor school-family enrichment model, selected as best fitting from the EFA, were evaluated using CFA conducted using IBM's SPSS Amos version 24. The following indicators of model fit were examined: The Tucker-Lewis index (TLI), the comparative fit index (CFI), the root mean square error of approximation (RMSEA), chi-square $\left(\chi^{2}\right)$, and the critical ratio (CR) of the chi-square statistic divided by the degrees of freedom $\left(\chi^{2} / d f\right)$. Values close to 1.0 for each of the TLI and CFI are considered to signify a very good fit, although values over .90 or over .95 are considered acceptable (Hu \& Bentler, 1999). Models with RMSEA values of .05 or less have good fit; however, RMSEA values of .08 or less are reasonable (Kline, 2005). Although good-fitting models will have non-significant ( $p>$ .05) chi-square values, models with large sample sizes will almost always be statistically significant (Kline, 2005), which is not necessarily indicative of a lack of fit. For this reason, although chi-square was examined, other fit measures were also used. In addition, the critical ratio (CR) of the chi-square statistic divided by degrees of freedom was determined. With respect to the $\mathrm{CR}$, the criterion for acceptance varies across researchers, ranging from less than 2.0 (Ullman, 2001) to less than 5.0 (Schumacker \& Lomax, 2004).

\section{Results}

Results for each of the three steps are included next. Missing data were minimal due to the set-up of the survey (participants were required to complete all items before moving on to the next page; data were missing only for those who selected "I choose not to answer") and treated through the use of listwise deletion procedures for each analysis.

\section{Step 1: Exploratory Factor Analysis}

Exploratory factor analysis of the school-family conflict scale using maximum likelihood estimation with a promax rotation resulted in the extraction of three factors with eigenvalues above 1.0. These three factors accounted for 54\% of the total variance (Table 6 details factor eigenvalues and variance, as well as individual item factor loadings and communalities). All items were retained as they functioned adequately in the adapted scale: each had significant bivariate correlations $(\mathrm{p}<.05)$ with the other items, factor loadings on a single factor greater than .49 , and factor loadings on the other two factors less than .30 . 
Table 6. Factor loadings for three-factor school-family conflict model

\begin{tabular}{|c|c|c|c|c|}
\hline \multirow[b]{2}{*}{ Item } & \multicolumn{3}{|c|}{ Factor Loadings } & \multirow{2}{*}{$\frac{\text { Communalities }}{\mathrm{h}_{\mathrm{j}}{ }^{2}}$} \\
\hline & $\mathrm{F}_{1}$ & $\mathrm{~F}_{2}$ & $\mathrm{~F}_{3}$ & \\
\hline \multicolumn{5}{|c|}{ Factor 1: School-to-family conflict } \\
\hline 1.1 & .78 & & & .59 \\
\hline 1.3 & .78 & & & .59 \\
\hline 1.4 & .76 & & & .62 \\
\hline 1.5 & .74 & & & .65 \\
\hline 1.2 & .70 & & & .42 \\
\hline 1.6 & .68 & & & .57 \\
\hline \multicolumn{5}{|c|}{ Factor 2: Family-to-school conflict } \\
\hline 1.14 & & .82 & & .68 \\
\hline 1.15 & & .80 & & .63 \\
\hline 1.13 & & .80 & & .64 \\
\hline 1.10 & & .69 & & .46 \\
\hline 1.11 & & .59 & & .37 \\
\hline 1.12 & & .53 & & .28 \\
\hline \multicolumn{5}{|c|}{ Factor 3: Behaviour-based conflict } \\
\hline 1.18 & & & .92 & .77 \\
\hline 1.16 & & & .88 & .71 \\
\hline 1.7 & & & .68 & .53 \\
\hline 1.17 & & & .65 & .48 \\
\hline 1.9 & .31 & & .54 & .44 \\
\hline 1.8 & & & .49 & .31 \\
\hline Variance explained (\%) & 35 & 10 & 9 & 54 \\
\hline Eigenvalues & 6.32 & 1.71 & 1.68 & 9.71 \\
\hline
\end{tabular}

Note: Factor loadings $<.30$ have been removed.

Submitting the school-family enrichment scale to an EFA, a four-factor solution was initially extracted using maximum likelihood estimation with a promax rotation. A fivefactor solution was ultimately selected as it improved on the four-factor model, demonstrating good fit, acceptable factor loadings, and the most parsimonious factor structure. This model explained $70 \%$ of the total variance. (Table 7 details factor eigenvalues and variance, as well as individual item factor loadings and communalities.) All items functioned adequately in the adapted scale: each had significant bivariate correlations $(\mathrm{p}<$ .05) with the other items, factor loadings on a single factor greater than .49 , and factor loadings on the other two factors less than .30. 
Table 7. Factor loadings for five-factor school-family enrichment model

\begin{tabular}{|c|c|c|c|c|c|c|}
\hline \multirow[b]{2}{*}{ Item } & \multicolumn{5}{|c|}{ Factor Loadings } & \multirow{2}{*}{$\begin{array}{c}\text { Communalities } \\
\mathrm{h}_{\mathrm{j}}{ }^{2}\end{array}$} \\
\hline & $\mathrm{F}_{1}$ & $\mathrm{~F}_{2}$ & $\mathrm{~F}_{3}$ & $\mathrm{~F}_{4}$ & $\mathrm{~F}_{5}$ & \\
\hline \multicolumn{7}{|c|}{ Factor 1: School-to-family growth } \\
\hline 2.9 & .97 & & & & & .81 \\
\hline 2.8 & .92 & & & & & .76 \\
\hline 2.7 & .83 & & & & & .75 \\
\hline 2.2 & .77 & & & & & .68 \\
\hline 2.3 & .64 & & & & & .57 \\
\hline 2.1 & .59 & & & & & .43 \\
\hline \multicolumn{7}{|c|}{ Factor 2: Family-to-school affect } \\
\hline 2.15 & & .94 & & & & .85 \\
\hline 2.13 & & .85 & & & & .77 \\
\hline 2.14 & & .75 & & & & .66 \\
\hline \multicolumn{7}{|c|}{$\begin{array}{l}\text { Factor 3: Family-to-school develop- } \\
\text { ment }\end{array}$} \\
\hline 2.10 & & & .80 & & & .66 \\
\hline 2.12 & & & .76 & & & .71 \\
\hline 2.11 & & & .75 & & & .72 \\
\hline \multicolumn{7}{|c|}{ Factor 4: Family-to-school efficiency } \\
\hline 2.17 & & & & .83 & & .72 \\
\hline 2.16 & & & & .71 & & .52 \\
\hline 2.18 & & & & .66 & & .54 \\
\hline \multicolumn{7}{|c|}{ Factor 5: School-to-family affect } \\
\hline 2.4 & & & & & .80 & .77 \\
\hline 2.6 & & & & & .78 & .81 \\
\hline 2.5 & & & & & .68 & .78 \\
\hline Variance explained (\%) & 44 & 14 & 4 & 4 & 3 & 69 \\
\hline Eigenvalues & 7.92 & 2.57 & .75 & .76 & .50 & 12.50 \\
\hline
\end{tabular}

Note: Factor loadings $<.30$ have been removed.

\section{Step 2: Assessment of the Scales' Reliability and Construct Validity}

Descriptive statistics for the final factor structures of the adapted scales are presented in Table 8. Cronbach's alpha estimates of the internal reliability for the adapted scales were acceptable, ranging from .81 to .92 .

A correlational analysis of a nomological network of relationships based on previous work-family research assessed hypothesized relationships with the school-family conflict scale. Significant negative correlations $(\mathrm{p}<.05)$ were expected between school-to-family conflict and school satisfaction and life satisfaction. Significant negative correlations were 
expected between family-to-school conflict and family satisfaction, family social support, and life satisfaction. As the behaviour-based conflict subscale encompassed items from both domains, it was expected to demonstrate relationships analogous to the other two subscales for both domains. The correlations are presented in Table 9, with 9 out of the 10 correlations significant and in the expected direction, providing support for the validity of the final factor structure of the adapted conflict scale.

Table 8. Means, standard deviations and Cronbach's alpha reliability estimates for the final factor structures of the adapted scales

\begin{tabular}{|c|c|c|c|c|c|c|}
\hline Variable & $n$ & $\begin{array}{c}\text { \# of } \\
\text { items }\end{array}$ & Range & $M$ & $S D$ & $\alpha$ \\
\hline \multicolumn{7}{|l|}{ School-Family Conflict ${ }^{a}$} \\
\hline School-to-family conflict & 333 & 6 & $6-30$ & 20.47 & $5 \cdot 53$ & .88 \\
\hline Behaviour-based conflict & 330 & 6 & $6-30$ & 16.63 & 4.60 & .86 \\
\hline Family-to-school conflict & 332 & 6 & $6-30$ & 18.83 & 5.18 & .86 \\
\hline \multicolumn{7}{|l|}{ School-Family Enrichment ${ }^{\mathrm{a}}$} \\
\hline School-to-family growth & 336 & 6 & $6-30$ & 24.24 & 4.36 & .92 \\
\hline School-to-family affect & 338 & 3 & $3-15$ & 10.42 & 2.85 & .92 \\
\hline Family-to-school development & 336 & 3 & $6-15$ & 11.51 & 2.39 & .87 \\
\hline Family-to-school affect & 337 & 3 & $5-15$ & 11.29 & 2.40 & .90 \\
\hline Family-to-school efficiency & 337 & 3 & $6-15$ & 10.89 & 2.71 & .81 \\
\hline
\end{tabular}

Table 9. Correlational relationship assessment: School-family conflict $(N=339)$

\begin{tabular}{lccc}
\hline & $\begin{array}{c}\text { School-to-family } \\
\text { conflict }\end{array}$ & $\begin{array}{c}\text { Behaviour- } \\
\text { based conflict }\end{array}$ & $\begin{array}{c}\text { Family-to- } \\
\text { school conflict }\end{array}$ \\
\hline School antecedents (school-to-family) & & & - \\
$\quad$ School satisfaction & $-.28^{* *}$ & $-.31^{* *}$ & -- \\
$\begin{array}{l}\text { School-to-family outcomes } \\
\text { Life satisfaction }\end{array}$ & $-.30^{* *}$ & $-.30^{* *}$ & --- \\
Family antecedents (family-to-school) & & & \\
$\quad$ Family satisfaction & --- & $-.30^{* *}$ & $-.36^{* *}$ \\
$\quad$ Family social support & -- & $-.24^{* *}$ & $-.28^{* *}$ \\
Family-to-school outcomes & & & \\
$\quad$ Life satisfaction & --- & .004 & $-.37^{* *}$ \\
\hline
\end{tabular}

${ }^{*} p<.05,{ }^{* *} p<.01,{ }^{* * *} p<.001$ 
Significant positive correlations were expected for the school-family enrichment scale between the two school-to-family subscales (growth and affect) and salience of the student role, school satisfaction, and positive affect. Significant negative correlations were expected for negative affect. As well, significant positive correlations were expected between the three family-to-school subscales (development, affect, and efficiency) and salience of the family role, family satisfaction, and positive affect. Significant negative correlations were expected for negative affect. The correlations are presented in Table 10 with 19 out of the 20 correlations significant and in the expected direction, providing support for the construct validity of the final factor structure of the adapted enrichment scale.

Table 10. Correlational relationship assessment: School-family enrichment $(N=339)$

\begin{tabular}{|c|c|c|c|c|c|}
\hline & $\begin{array}{l}\text { School- } \\
\text { to-family } \\
\text { growth }\end{array}$ & $\begin{array}{l}\text { School- } \\
\text { to-family } \\
\text { affect }\end{array}$ & $\begin{array}{l}\text { Family-to- } \\
\text { school devel- } \\
\text { opment }\end{array}$ & $\begin{array}{l}\text { Family- } \\
\text { to-school } \\
\text { affect }\end{array}$ & $\begin{array}{l}\text { Family- } \\
\text { to-school } \\
\text { efficiency }\end{array}$ \\
\hline \multicolumn{6}{|l|}{$\begin{array}{l}\text { School antecedents (school- } \\
\text { to-family) }\end{array}$} \\
\hline Salience of student role & $.36^{* *}$ & $.31^{* *}$ & --- & --- & --- \\
\hline \multicolumn{6}{|l|}{ School-to-family outcomes } \\
\hline School satisfaction & $.35^{* *}$ & $.40^{* *}$ & --- & --- & --- \\
\hline Positive affect & $.47^{* *}$ & $.49^{* *}$ & --- & --- & --- \\
\hline Negative affect & $-.31^{* *}$ & $-.33^{* *}$ & --- & --- & --- \\
\hline \multicolumn{6}{|l|}{$\begin{array}{l}\text { Family antecedents (family- } \\
\text { to-school) }\end{array}$} \\
\hline Salience of family role & --- & --- & $.13^{*}$ & $.16^{* *}$ & .05 \\
\hline \multicolumn{6}{|l|}{ Family-to-school outcomes } \\
\hline Family satisfaction & --- & --- & $.25^{* *}$ & $.42^{* *}$ & $.27^{* *}$ \\
\hline Positive affect & --- & --- & $.29^{* *}$ & $.36^{* *}$ & $.41^{* *}$ \\
\hline Negative affect & --- & --- & $-.16^{* *}$ & $-.21^{* *}$ & $-.25^{* *}$ \\
\hline
\end{tabular}

${ }^{*} p<.05,{ }^{* *} p<.01,{ }^{* * *} p<.001$

\section{Step 3: Confirmatory Factor Analysis}

Subjecting the three-factor school-family conflict model derived from the EFA to a CFA failed to confirm adequate fit of the model (Table 11). While the CR $\left(\chi^{2} / d f\right)$ was in an acceptable range (i.e., between 2.0 and 5.0; Schumacker \& Lomax, 2004; Ullman, 2001), the CFA returned a TLI of .85 and a CFI of .89, both below the accepted minimum standard of .90 (Hu \& Bentler, 1999). Moreover, a RMSEA value of .11 exceeds the maximum standard of .o8 (Kline, 2005). Figure 1 depicts the final model with standardized estimates. Potential modifications to improve the goodness of fit were explored, including removal of weaker items; however, no significant improvements were made and the decision was made to retain the model, including all of the items from the original scale for comparison purposes.

The five-factor school-family enrichment model was found to have adequate fit for all but one measure of model fit (Table 11). Although the RMSEA (.09) was slightly above accepted standards, CR $\left(\chi^{2} / d f\right)$, TLI, and CFI values of $3.58, .92$, and .94, respectively 
indicate adequate fit. Figure 2 depicts the final model with standardized estimates. Each model included two correlated residual terms for closely related items that involved some redundancy in their content (school-to-family conflict and family-to-school conflict factors in Figure 1; school-to-family growth factor in Figure 2) as per previous work with these scales (van Rhijn, 2009).

Table 11. CFA of school-family conflict and school-family enrichment: Indicators of model fit

\begin{tabular}{lccccccc}
\hline Model & CFI & TLI & RMSEA & $\chi^{2}$ & df & CR $\left(\chi^{2} / d f\right)$ & $p$ \\
\hline School-family conflict & .89 & .85 & .11 & 546.43 & 129 & 4.24 & $* * *$ \\
School-family enrichment & .94 & .92 & .09 & 439.92 & 123 & 3.58 & $* * *$ \\
\hline
\end{tabular}

${ }^{*} p<.05,{ }^{* *} p<.01,{ }^{* * *} p<.001$

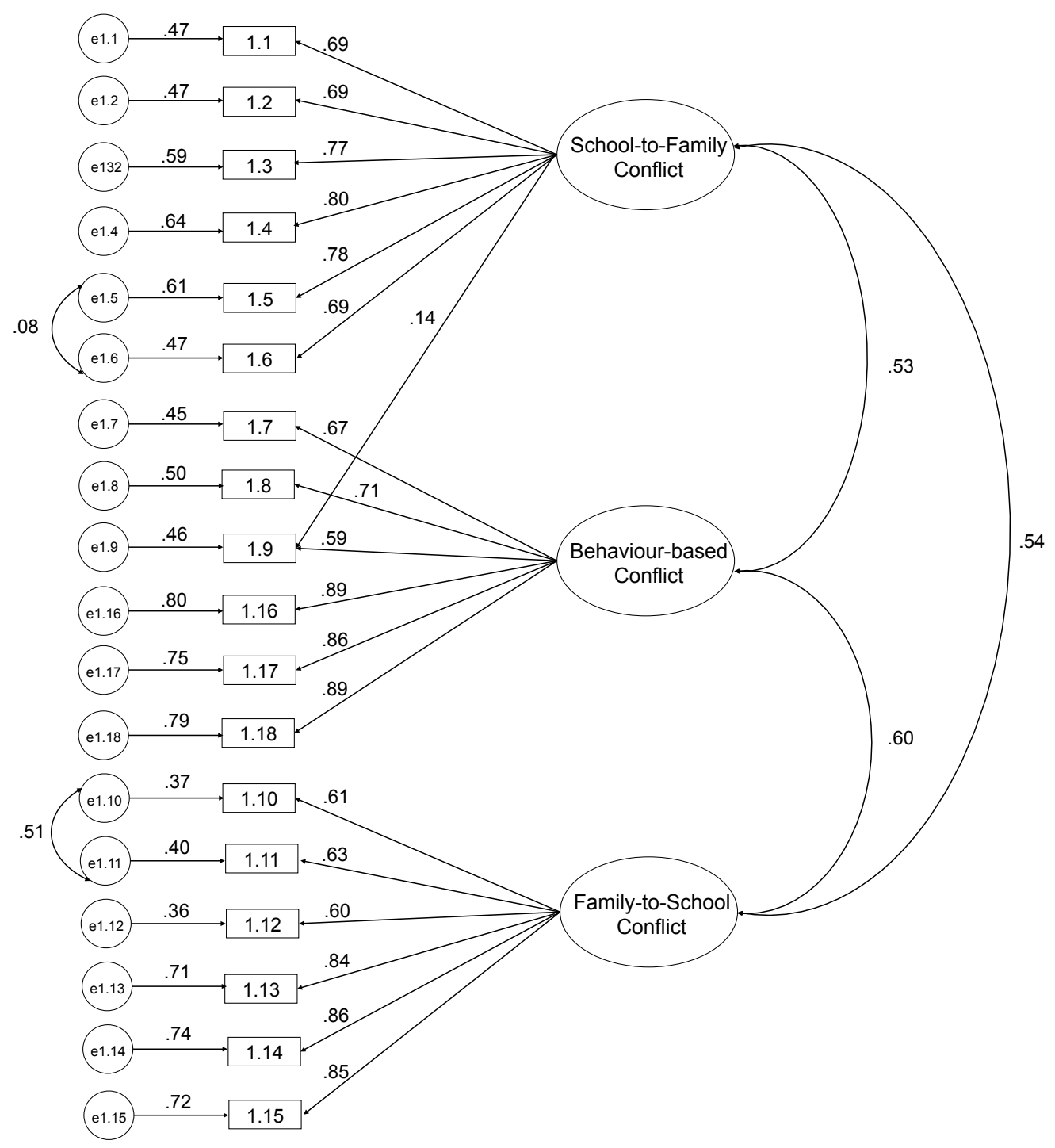

Figure 1. Confirmatory factor analysis results for final school-family conflict model, standardized estimates 


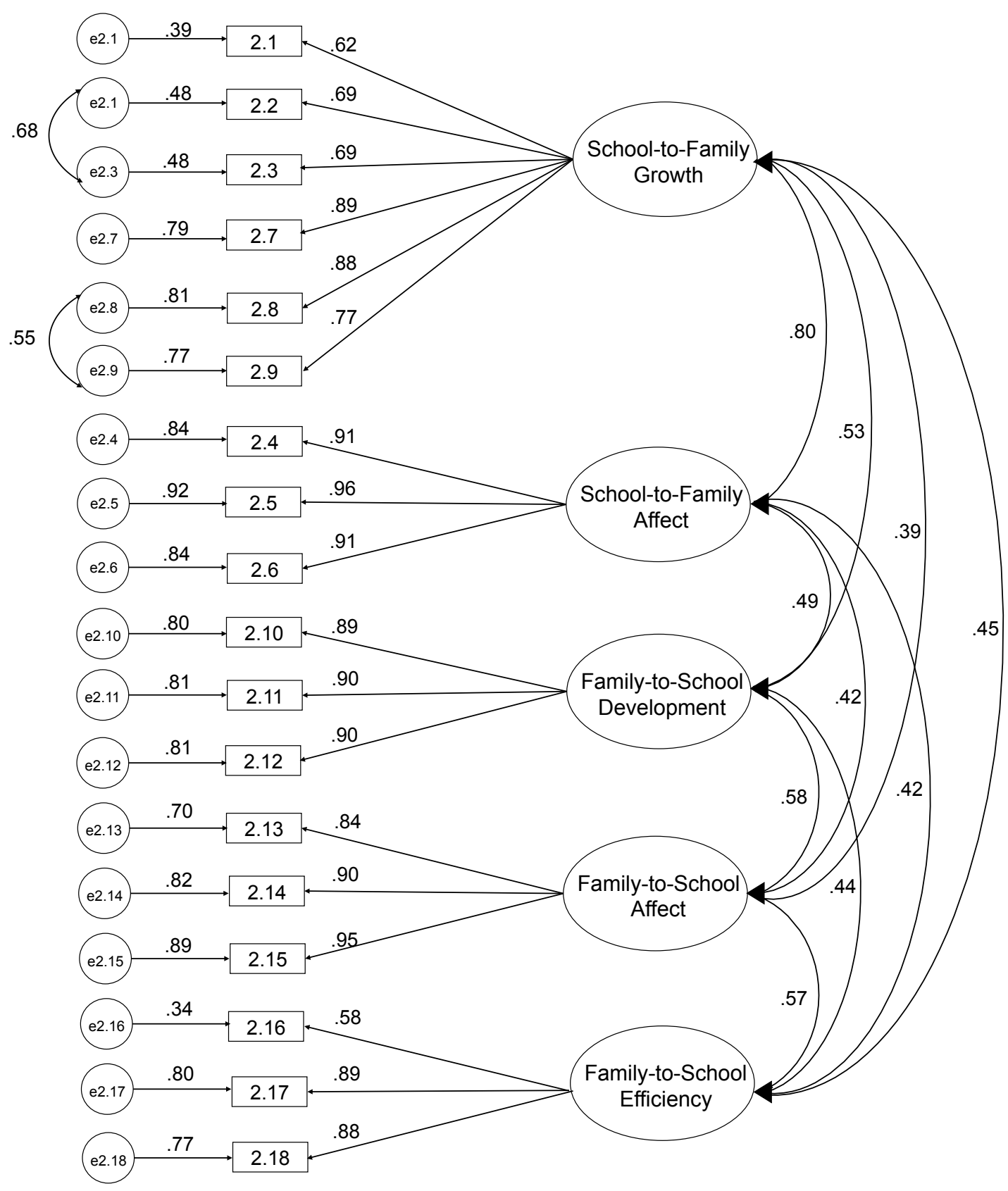

Figure 2. Confirmatory factor analysis results for final school-family enrichment model, standardized estimates

\section{Discussion}

The primary purpose of this study was to examine the utility of the adapted SchoolFamily Conflict Scale and School-Family Enrichment Scale for use with undergraduate student parents. This section will review evidence for the factorial validity, reliability, and construct validity of the adapted scales, in addition to discussing the significance and implications of the findings. Study strengths and limitations and directions for future research will also be presented. 
Exploratory factor analyses demonstrated some differences in the factor structures of both the school-family conflict and enrichment measures from the original work-family measures. School-family conflict was best represented by a three-factor structure consisting of school-to-family conflict, family-to-school conflict, and behaviour-based conflict. The factors were similar to the original measures, as two of the factors retained the dimensionality of two distinct domains, school-to-family and family-to-school. The behaviour-based-conflict factor, clearly a unique dimension, combined the domains. This finding may indicate that behaviour-based conflict occurs simultaneously in both directions for undergraduate student parents, as opposed to having distinct school-to-family or family-to-school directions; however, future work is recommended in order to clarify this relationship. The factor structure for school-family enrichment was closer to the original measure, but with one less factor. It was best represented by a five-factor structure consisting of school-to-family growth, school-to-family affect, family-to-school development, family-to-school affect, and family-to-school efficiency.

The final factor structures for both adapted scales were found to have high levels of internal reliability, with Cronbach's alpha values ranging from .86 to .88 for the schoolfamily conflict factors and from .81 to .92 for school-family enrichment. Overall, the findings supported the factorial validity and reliability of the new measures, clearly distinguishing the school-to-family and family-to-school domains and the unique dimensions within each. Although work and school roles share many similar features, it is likely that some differences in the roles led to the minor variations in factor structure that were observed. Differences may include the temporary nature and salience of the student role, which could enhance student parents' ability to maintain a focus on perceived future benefits related to the attainment of a post-secondary education.

Construct validity was evaluated through a nomological network analysis of the factor structure of the final scales. The factors all demonstrated significant correlations with a majority of the antecedent and outcome variables, except for behaviour-based conflict from the school-family conflict measure, which was not significantly correlated with life satisfaction. Behaviour-based conflict was the only factor that combined items from the original measures from both domains, possibly contributing to this discrepant finding. As the original scales were examined with the two separate domains for behaviour-based conflict, it is clear that this combination requires further examination to clarify whether this factor has unique antecedent constructs.

Confirmatory factor analysis of the selected factor structures failed to confirm adequate fit of the initial three-factor school-family conflict model, but suggested adequate fit of the initial five-factor school-family enrichment model. A potential explanation for the inadequate fit of the school-family conflict model may be related to systematic differences between the sample used for the EFA and the sample used for the CFA. The percentage of women was considerably higher in the EFA sample (87\%) than in the CFA sample (76\%), while the percentage of university students was higher in the CFA sample (98\%) than in the EFA sample (84\%), as was the mean age of participants (39.18 vs. 34.56). It is possible that school-family conflict may function differently for participants in a way that is dependent on gender and/or institution type. Thus, while the School-Family Conflict Scale appears to have acceptable internal consistency and construct validity, results of the CFA suggest that it should be used with caution, as model fit may be suboptimal. The School-Family 
Enrichment Scale results, however, provide strong support that it is a valid instrument for measuring school-family enrichment among undergraduate university students who are parents. Since both scales have been successfully used in research involving university student parents (e.g., Andrade, van Rhijn, \& Coimbra, 2017; Swingle, 2013), this study provides additional support for the use of these measures and a starting point for further development and testing, particularly of the School-Family Conflict Scale.

This study has a number of strengths, including the use of well-validated measures, multiple samples, and rigorous statistical techniques; however, there are also a number of limitations that merit consideration. Although the sample sizes were acceptable for the scope of the research, neither sample was representative with regard to gender and institution type. College students, in particular, were underrepresented in both samples used in this study. Although the findings still held in a separate analysis in which college students were removed from the first sample, further research is required to confirm the validity of these scales among college students who are parents, particularly because the college environment can be quite different from that of a university. In addition to limiting the types of analyses that could be conducted, the under-representation of certain demographic groups in the study samples also suggests that certain subpopulations of student parents are less accessible, such as male student parents. Previous research has demonstrated that student parents are much more likely to be female (van Rhijn et al., 2011); yet both samples had higher proportions of females than would be expected. Additionally, as recruitment concentrated on avenues through which student parents might be contacted, there may be selection or response biases in the resulting samples such that they could be more representative of those connected with on-campus resources and supports.

While in the second sample the focus of the study was exclusively on university students, the differences in the number of participants attending university and college in the first sample were a consequence of more successful recruitment methods being employed at two universities (a course website posting that was visible to all students and an email sent by one large department to their entire listserv). It is recommended that these highly successful methods of recruiting student parents be used where possible in future work for several reasons: (1) they are highly effective ways to reach student parents regardless of their level of connection on their post-secondary campuses; and (2) post-secondary institutions now communicate with their students primarily through electronic means such as course sites, institutional websites, and email, making electronic recruitment and data collection an ideal method to conduct research with this difficult-to-access population. Finally, there was an extended time period between the data collection points (2008 to 2012) to complete this validation study. The extended time period was due to the time it took to set up the second study and come to an agreement to include the school-family conflict and enrichment scales in the survey.

\section{Conclusions and Directions for Future Research}

This study demonstrates the utility of the adapted work-family conflict and enrichment scales to measure school-family conflict and enrichment of university student parents in post-secondary education. Both scales were found to be reliable and valid for use with university student parents. In addition, CFA provided strong support for the factor structure of the school-family enrichment scale. While the factor structure of the school- 
family conflict scale may require further testing and development, the description of the psychometric properties of these two scales lays a strong foundation for further research in this area.

Future work moving beyond the assessment of these measurement models and toward the evaluation of structural models is also recommended. Evaluation of a conceptual model of school-family interaction is required in order to develop an understanding of the relationship between school-family conflict and enrichment and various antecedent and outcome constructs suggested by work-family research (e.g., Frone et al., 1997). This evaluation would allow for further comparison with the work-family literature. Although the work-family interface and school-family interface are theoretically similar, further assessment and evaluation of their similarities and differences is recommended. Some indication of one difference was evident in that a significant correlational relationship was found between school-family conflict and enrichment. This differs from work-family findings (e.g., Carlson et al., 2006; Kinnunen et al., 2006) and may be related to the greater permeability of boundaries between the roles of student and family member/parent compared to those of worker and family member. The boundaries between school and family roles are much more permeable in that school-related tasks often take place in the home (e.g., working on an assignment in the evening or on a weekend) and family-related tasks are more likely to take place at school (e.g., receiving a phone call from a childcare provider). This greater permeability is likely similar to that experienced by individuals who work from home or are self-employed, and should be examined in future research.

Further exploration of the relationship between conflict and enrichment is necessary to determine how they jointly impact quality of life and if enrichment might act to moderate the influence of conflict on well-being. Other areas not included in this research but that are likely to be important areas of inquiry include the availability and effectiveness of institutional supports and resources, the impact of feeling socially excluded as a nontraditional student, the transition to the student role, and challenges related to simultaneously occupying student, family, and employment roles. Another natural extension of the present research would be to translate the adapted scales to other languages, such as French, and gather additional validity evidence for the internal structure of these scales using French-speaking participants.

With more adults continuing their education due to employers' increasing requirement of post-secondary credentials and economic pressures (e.g., job uncertainty, layoffs, the need for career retraining), it is important to develop an understanding of the impacts of combining the multiple roles of school, family, and work experienced by student parents. Higher levels of conflict and increased strain may be part of the reason that this population is found to be at a higher risk of interrupting or discontinuing their studies. Many universities and colleges are expressing interest in supporting this population and are beginning to develop programs that are specific to the needs of student parents. The development of these measures is necessary in order to assess the success of such programs. In addition, using research to assess school-family conflict and enrichment is important in order to provide direction to policy makers regarding the development of future programs to support this growing minority population to successfully access, persist in, and complete post-secondary education programs. 


\section{Acknowledgements}

This study was made possible as a result of funding received from the Social Sciences and Humanities Research Council of Canada and the Jarislowsky Chair for Families \& Work.

\section{References}

Alfonso, V. C., Allison, D. B., Rader, D. E., \& Gorman, B. S. (1996). The extended satisfaction with life scale: Development and psychometric properties. Social Indicators Research, 38(3), 275-301. https://doi.org/10.1007/BFo0292049

Andrade, C., van Rhijn, T., \& Coimbra, S. (2017). Gender differences in school-family conflict and family enrichment in nontraditional Portuguese students. The Journal of Continuing and Higher Education 65(1), 13-24. https://doi.org/10.1080/07377363.20 17.1272439

Butlin, G. (1999). Determinants of postsecondary participation. Education Quarterly Review, 5(3), 9-31. Retrieved from http://www5.statcan.gc.ca/olc-cel/olc. action?ObjId=81-003-X19980034470\&ObjType=47\&lang=en

Byron, K. (2005). A meta-analytic review of work-family conflict and its antecedents. Journal of Vocational Behavior, 67(2), 169-198. https://doi.org/10.1016/j. jvb.2004.08.009

Carlson, D. S., Kacmar, K. M., Wayne, J. H., \& Grzywacz, J. G. (2006). Measuring the positive side of the work-family interface: Development and validation of a workfamily enrichment scale. Journal of Vocational Behavior, 68(1), 131-164. https://doi. org/10.1016/j.jvb.2005.02.002

Carlson, D. S., Kacmar, K. M., \& Williams, L. J. (2000). Construction and validation of a multidimensional measure of work-family conflict. Journal of Vocational Behavior, 56(2), 249-276. https://doi.org/10.1006/jvbe.1999.1713

Crouter, A. C., \& McHale, S. M. (2005). The long arm of the job revisited: Parenting in dual-earner families. In T. Luster \& L. Okagaki (Eds.), Parenting: An ecological perspective (Vol. 2, pp. 275-296). Mahwah, NJ: Lawrence Erlbaum Associates, Inc.

Diener, E., Emmons, R., Larsen, R., \& Griffin, S. (1985). The satisfaction with life scale. Journal of Personality Assessment, 49(1), 71-75. https://doi.org/10.1207/ s15327752jpa4901_13

Eisinga, R., Grotenhuis, M., \& Pelzer, B. (2013). The reliability of a two-item scale: Pearson, Cronbach, or Spearman-Brown? International Journal of Public Health, 58, 637-642. https://doi.org/10.1007/s00038-012-0416-3

Fabrigar, L. R., Wegener, D. T., MacCallum, R. C., \& Strahan, E. J. (1999). Evaluating the use of exploratory factor analysis in psychological research. Psychological Methods, 4(3), 272-299. https://doi.org/10.1037/1082-989X.4.3.272

Frone, M. R., Yardley, J. K., \& Markel, K. S. (1997). Developing and testing an integrative model of the work-family interface. Journal of Vocational Behaviour, 5O(2), 145-167. https://doi.org/10.1006/jvbe.1996.1577 
Greenhaus, J. H., \& Beutell, N. J. (1985). Sources of conflict between work and family roles. Academy of Management Review, 1O(1), 76-88. https://doi.org/10.5465/ AMR.1985.4277352

Greenhaus, J. H., \& Powell, G. N. (2003). When work and family collide: Deciding between competing role demands. Organizational Behavior and Human Decision Processes, 9o(2), 291-303. https://doi.org/10.1016/So749-5978(02)00519-8

Hammer, L. B., Cullen, J. C., Neal, M. B., Sinclair, R. R., \& Shafiro, M. V. (2005). The longitudinal effects of work-family conflict and positive spillover on depressive symptoms among dual-earner couples. Journal of Occupational Health Psychology, 10(2), 138-154. https://doi.org/10.1037/1076-8998.10.2.138

Hammer, L. B., Grigsby, T. D., \& Woods, S. (1998). The conflicting demands of work, family, and school among students at an urban university. Journal of Psychology, 132(2), 220-226. https://doi.org/10.1080/o0223989809599161

Hanson, G. C., Hammer, L. B., \& Colton, C. L. (2006). Development and validation of a multidimensional scale of perceived work-family positive spillover. Journal of Occupational Health Psychology, 11(3), 249-265. https://doi.org/10.1037/10768998.11.3.249

Haslam, D., Filus, A., Morawska, A., \& Fletcher, R. (2015). The Work-Family Conflict Scale (WAFCS): Development and initial validation of a self-report measure of workfamily conflict for use with parents. Child Psychiatry and Human Development, 46(3), 346-357. https://doi.org/10.1007/s10578-014-0476-o

Holmes, D. (2005). Embracing differences: Post-secondary education among aboriginal students, students with children and students with disabilities. Retrieved from https://qspace.library.queensu.ca/bitstream/handle/1974/5746/embracing_en.pd f;jsessionid=Bo5D87F2A2CF7793A34D38CD9CC91CBE?sequence =1

Home, A. M. (1997). Learning the hard way: Role strain, stress, role demands, and support in multiple-role women students. Journal of Social Work Education, 33(2), 335347. https://doi.org/10.1080/10437797.1997.10778874

Hu, L.-t., \& Bentler, P. M. (1999). Cutoff criteria for fix indexes in covariance structure analysis: Conventional criteria versus new alternatives. Structural Equation Modeling: A Multidisciplinary Journal, 6(1), 1-55. https://doi.org/10.1080/10705519909540118

Johnston, C., \& Mash, E. J. (1989). A measure of parenting satisfaction and efficacy. Journal of Clinical Child Psychology, 18(2), 167-175. https://doi.org/10.1207/ s15374424jccp1802_8

Kerr, A. (2011). Adult learners in Ontario postsecondary institutions. Retrieved from http://www.heqco.ca/en-ca/Research/ResPub/Pages/Issue-Paper-No-9-Informingpolicy-through-analysis-of-current-research.aspx

Kinnunen, U., Feldt, T., Geurts, S., \& Pulkkinen, L. (2006). Types of work-family interface: Well-being correlates of negative and positive spillover between work and family. Scandinavian Journal of Psychology, 47(2), 149-162. https://doi.org/10.1111/ j.1467-9450.2006.00502.x 
Kline, R. B. (2005). Principles and practice of structural equation modeling. New York, NY: Guilford Press.

Kuh, G. D., Kinzie, J., Buckley, J. A., Bridges, B. K., \& Hayek, J. C. (2006). What matters to student success: A review of the literature. Retrieved from https://nces. ed.gov/npec/pdf/kuh_team_report.pdf

Lodahl, T. M., \& Kejner, M. (1965). The definition and measurement of job involvement. Journal of Applied Psychology, 49(1), 24-33. https://doi.org/10.1037/hoo21692

Looker, D. E. (1997). In search of credentials: Factors affecting young adults' participation in postsecondary education. Canadian Journal of Higher Education, $27(2 / 3), 1-36$. Retrieved from http://journals.sfu.ca/cjhe/index.php/cjhe/article/ view/183302

MacAri, D. P., Maples, M. F., \& D'Andrea, L. (2005). A comparative study of psychosocial development in nontraditional and traditional college students. Journal of College Student Retention: Research, Theory \& Practice, 7(3), 283-302. https://doi. org/10.2190/BV5H-3630-18CU-6C3B

Mullen, J., Kelley, E., \& Kelloway, E. K. (2008). Health and well-being outcomes of the work-family interface. In K. Korabik, D. S. Lero, \& D. L. Whitehead (Eds.), Handbook of work-family integration: Research, theory, and best practices (pp. 191-214). San Diego, CA: Elsevier.

Padula, M. A. (1994). Reentry women: A literature review with recommendations for counseling and research. Journal of Counseling and Development, 73(1), 10-16. https:// doi.org/10.1002/j.1556-6676.1994.tbo1703.x

Quimby, J. L., \& O'Brien, K. M. (2006). Predictors of well-being among nontraditional female students with children. Journal of Counseling and Development, 84(4), 451-460. https://doi.org/10.1002/j.1556-6678.2006.tbo0429.x

Schumacker, R. E., \& Lomax, R. G. (2004). A beginner's guide to structural equation modeling (3rd ed.). Mahwah, NJ: Lawrence Erlbaum Associates, Inc.

Statistics Canada. (2017). Labour force survey, October 2017 [Public use microdata files]. Retrieved from https://search2.odesi.ca/\#/details?uri=\%2Fodesi\%2Flfs71Mooo1-E-2017-october.xml

Swingle, A. L.-V. (2013). College student parents: Stress, role conflict, and coping (Doctoral dissertation). Indiana University of Pennsylvania, Indiana, PA. Retrieved from http://knowledge.library.iup.edu/cgi/viewcontent.cgi?article=1033\&context=etd

Tabachnick, B. G., \& Fidell, L. S. (2000). Using multivariate statistics ( $4^{\text {th }}$ ed.). Needham Heights, MA: Allyn \& Bacon.

Theodore, N., \& Peck, J. (1999). Welfare-to-work: National problems, local solutions? Critical Social Policy, 19(4), 485-510. https://doi.org/10.1177/026101839901900404

Ullman, J. B. (2001). Structural equation modeling. In B. G. Tabachnick \& L. S. Fidell (Eds.), Using multivariate statistics (4th ed., pp. 653-771). Needham Heights, MA: Allyn \& Bacon. 
van Rhijn, T. (2009). School-family conflict and enrichment in undergraduate student parents (master's thesis). University of Guelph, Ontario, Canada.

van Rhijn, T., Lero, D. S., Bridge, K., \& Fritz, V. A. (2016). Unmet needs: Challenges to success from the perspectives of mature university students. The Canadian Journal for the Study of Adult Education, 28(1), 29-47. Retrieved from https://cjsae.library.dal.ca/ index.php/cjsae/article/view/4704

van Rhijn, T., \& Poser, B. (2013). Mature Student Experience Survey: Summary report. Retrieved from http://hdl.handle.net/10214/9298

van Rhijn, T., Smit Quosai, T. \& Lero, D. (2011). A profile of undergraduate student parents in Canada. Canadian Journal of Higher Education, 43(3), 59-80. Retrieved from http://journals.sfu.ca/cjhe/index.php/cjhe/article/view/59

Van Stone, N., Nelson, J. R., \& Niemann, J. (1994). Poor single-mother college students' views on the effect of some primary sociological and psychological belief factors on their academic success. The Journal of Higher Education, 65(5), 571-584. https:// doi.org/10.2307/2943779

Voydanoff, P. (2005). Work demands and work-to-family and family-to-work conflict: Direct and indirect relationships. Journal of Family Issues, 26(6), 707-726. https://doi. org/10.1177/0192513x05277516

Watson, D., Clark, L. A., \& Tellegen, A. (1988). Development and validation of brief measures of positive and negative affect: The PANAS scales. Journal of Personality and Social Psychology, 54(6), 1063-1070. https://doi.org/10.1037//0022-3514.54.6.1063

Wyatt, L. G. (2011). Nontraditional student engagement: Increasing adult student success and retention. The Journal of Continuing Higher Education, 59(1), 10-20. https://doi.org/10.1080/07377363.2011.544977

$\mathrm{Xu}, \mathrm{L}$. , \& Song, R. (2013). Development and validation of the work-family-school role conflicts and role-related social support scales among registered nurses with multiple roles. International Journal of Nursing Studies, 5o(10), 1391-1398. https://doi.org/10.1016/j. ijnurstu.2013.01.003

Zajacova, A., Lynch, S. M., \& Espenshade, T. J. (2005). Self-efficacy, stress, and academic success in college. Research in Higher Education, 46(6), 677-706. https://doi. org/10.1007/s11162-004-4139-z

Zimet, G., Dahlem, N., Zimet, S., \& Farley, G. (1988). The multidimensional scale of perceived social support. Journal of Personality Assessment, 52(1), 30-41. https://doi. org/10.1207/s15327752jpa5201_2

\section{Contact Information}

Tricia van Rhijn

Department of Family Relations and Applied Nutrition

University of Guelph

tricia.vanrhijn@uoguelph.ca 
Tricia van Rhijn is Associate Professor in the Department of Family Relations and Applied Nutrition at the University of Guelph. Her research interests include early childhood education and care, family relations, work-life integration, and the experiences of non-traditional students in formal post-secondary education, in particular mature students and student parents.

Anita Acai is a PhD student in the Department of Psychology, Neuroscience \& Behaviour and the Office of Education Science, Department of Surgery at McMaster University. She is currently studying the group decision-making processes of competence committees, which assess residents' progression through competency-based medical training programs. She also maintains active research interests in a number of other areas of health professions education, gender equity and work-life integration in higher education, and the scholarship of teaching and learning.

Donna Lero is Professor Emerita in the Department of Family Relations and Applied Nutrition at the University of Guelph. She co-founded the University's Centre for Families, Work and Well-being and served as the Inaugural Jarislowsky Chair in Families and Work from 2003-2016. Dr. Lero continues to be involved in research and policy analysis in work-family integration, parental leave, caregiving and work, and disabilities and employment. 